\title{
Quality Improvement of Wool Fabric Using Protease Enzyme
}

\author{
Pooja, Ekta Sharma*, Nargis Fatima \\ Ethilind School of Home Science, Sam Higginbottom Institute of Agriculture, Technology \& Sciences(Formerly Allahabad \\ Agriculture Institute), India \\ *Corresponding Author: groverekta1@gmail.com
}

Copyright @ 2014 Horizon Research Publishing All rights reserved.

\begin{abstract}
Wool is a fiber from the fleece of domesticated sheep. The scaly structure of wool is responsible, to a great extent, for the tendency of wool to felt and shrink. Chlorination is a commonly used process to modify the scales of wool fibers with the purpose of providing resistance to felting and shrinkage but this process shows a number of drawbacks which forced to search for an ecologically clean alternative. There have been many attempts to replace this chlorine process by an environmental friendly process that would similarly degrade the scales. Enzyme processing is one of them that has come to forefront in the textile processing units and made processing more eco-friendly. In the present study an attempt was made to treat the wollen fabric with different concentrations (1, 2, 3, 4 and 5g/l) of Protease enzyme and observed the effects on physical properties including hand of the fabric, weight loss, Scanning Electron Microscope (SCM) test, absorbency, pilling, tensile strength, and fabric drape, dyeability as well as colour fastness properties of woolen fabrics. The control, scoured and enzyme treated samples were also tested and compared. All the samples were dyed with acid dye to check the effect of enzymatic degumming on dye ability of wool fabric. The dyed fabrics were subjected to testing for various colorfastness properties including light, washing, crocking and perspiration. Untreated wool fiber showed fair handle, no absorbency (60 seconds), rough and sharp scales on the surface of fiber, however enzyme treatment with different concentrations wool fabric showed improvement in softness, slight weight loss (6.31\%), smoother surface scales, improved absorbency (minimum 45 seconds) and drapability. Treatment with protease enzyme brought improvement in the physical and colorfastness properties of wool fabric. Among all the concentrations of protease enzyme, $4 \mathrm{~g} / \mathrm{l}$ concentration was found to be best.
\end{abstract}

Keywords Coarse Woolen Fabric, Enzyme Treatment, Physical and Colourfastness Properties, Protease Enzyme and Acid Dye

\section{Introduction}

Environment and ecology occupy a prominent place among the key focal issues faced by the world today. The natural fibres are eco-friendly and are easily disposable. They do not disturb the ecological balance of the environment. Wool, one of natural fibres, is fiber from the fleece of domesticated sheep. It is a natural, protein, multi-cellular, staple fiber. Wool consists of two major morphological parts: the cuticle and the cortex. The former is composed of overlapping cells (scales) that surround the latter. This scaly structure is responsible, to a great extent, for the tendency of wool to felt and shrink. Chlorination is a commonly used process to modify the scales of wool fibers with the purpose of providing resistance to felting and shrinkage. From today's point of view the chlorination process shows a number of drawbacks which make us search for an ecologically clean alternative worthwhile: limited durability, poor handle, yellowing of wool, difficulties in dyeing and the most important today, environmental impact. There have been many attempts to replace this chlorine process by an environmental friendly enzymatic process that would similarly degrade the scales.

Because of the new environmental directives, the development of clean technologies such as enzymatic finishing processes is a priority. Enzymes are natural protein molecules that act as highly efficient catalysts in biochemical reactions, i.e., they help a chemical reaction take place quickly and efficiently. This catalytic capability is what makes enzymes unique. Enzymes not only work efficiently and rapidly, but they are also biodegradable. Thus Keeping in mind these points, the present study was undertaken to treat the woven woolen fabric with protease enzyme using different concentrations, to determine the effect of enzyme treatment on dye ability and to find out the effect of protease enzyme on the physical and colourfastness properties of the woolen fabric.

\section{Methodology}

\subsection{Raw Materials}

Coarse woolen (woven) fabric and Alkaline Protease 
(SCL Pan 5) enzyme were used for the study.

\subsection{Pre-treatment of Woollen Fabric}

Before any finishing treatment, the wool fabric must be scoured in order to remove the natural and added impurities that can hinder the successful operation of application of enzyme. Scouring was done as per recipe given by Dantyagi [5]

$\begin{array}{ll}\text { Liquid soap (Ezee) } & : 0.5 \% \text { (o.w.f) } \\ \text { M:L } & : 1: 50 \\ \text { Temperature } & : 40^{\circ} \mathrm{C} \\ \text { Time duration } & : 30 \mathrm{~min}\end{array}$

A detergent solution containing $0.5 \mathrm{ml}$ of ezee per $100 \mathrm{ml}$ of water was prepared maintaining the material liquor ratio 1:50. It was heated to $40^{\circ} \mathrm{C}$ and wool fabric was dipped into this solution and stirred gently for about 30 minutes. It was kneaded and squeezed in soap solution and then rinsed under tap water. After that fabric was dried under shade.
Enzyme treatment was carried out on woven woolen fabric using alkaline protease (SCL Pan 5) enzyme having activity of $5000 \mathrm{u} / \mathrm{g}$. The following recipe was used for enzyme treatment of woolen fabric.

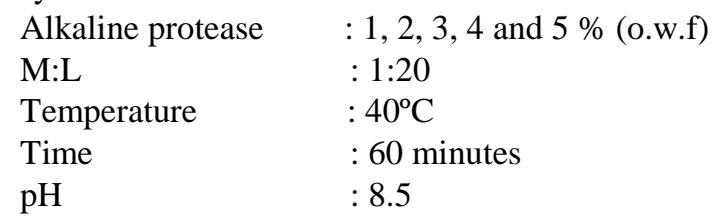

The solution for each concentration was prepared separately maintaining the material liquor ratio $1: 20$. The temperature was raised and maintained up to $40^{\circ} \mathrm{C}$. Samples were added to solution and treated for 60 minutes. After that, the samples were taken out and transferred into acidic solution maintaining the $\mathrm{pH} 5$ and kept for 20 minutes to stop the enzyme activity at the point and then rinse with cold water.

\subsection{Testing For Physical Properties:}

All the samples (control, scoured and enzyme treated) were subjected to various testing for physical properties in order to check the effect of treatment on these properties. The tests included:

\subsection{Enzyme Treatment}

\begin{tabular}{|c|c|c|c|}
\hline S.No & TEST & PURPOSE & TEST STANDARD \\
\hline 1. & Absorbency & To determine absorbency of fabric. & AATCC:79-2010 \\
\hline 2. & Fabric tensile test & To determine tensile strength of fabric. & $\begin{array}{c}\text { IS:1969(Part 2):2010/ISO } \\
\text { 13934-2:1999 }\end{array}$ \\
\hline 3. & Weight loss & To determine weight loss of fabric. & ASTM d 2720-94 (2012) e1 \\
\hline 4. & Pilling resistance & To determine pilling tendency of the fabric. & $\begin{array}{c}\text { IS:10971(Part } \\
\text { 1):2011/ISO/2945-2:2000 }\end{array}$ \\
\hline 5. & Fabric drape & To determine drapability of fabric. & ASTM D-737-04 (2012) \\
\hline 6. & Hand of fabric & To determine hand and feel of the fabric. & AATCC: EP 5 \\
\hline 7 & $\begin{array}{c}\text { SEM(scanning electron } \\
\text { microscope) }\end{array}$ & $\begin{array}{c}\text { To scan longitudinal and cross-sectional view } \\
\text { of fibre. }\end{array}$ & ZEISS EVO 50 instrument \\
\hline
\end{tabular}




\subsection{Dyeing of Wool Fabric}

All the wool samples i.e. control, untreated, scoured and enzymes treated were dyed with acid dye in order to find out the effect of enzyme treatment. The following recipe given by Shenai [7] was used for dyeing of samples.

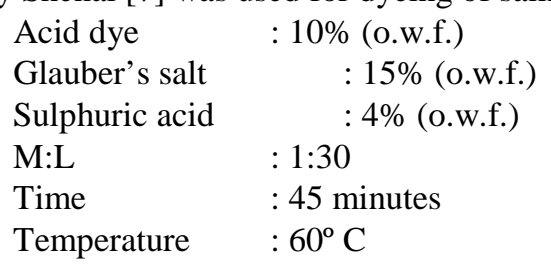

Dye paste was prepared by dissolving required amount of dye in small amount of water and sulphuric acid. More water was added to make the dye solution, keeping the material to liquor ratio 1:30. The samples were added to dye bath. Temperature was raised and maintained up to $60^{\circ} \mathrm{C}$ for 45 minutes, stirring was continued to ensure uniform dyeing. After dyeing the dyed samples were taken out from the dye bath, rinsed thoroughly with water and were dried under shade.

\subsection{Colourfastness Testing of Dyed Samples}

All the dyed samples were subjected to colour fastness tests which included-

\begin{tabular}{|c|c|c|c|}
\hline S.No. & TEST & $\begin{array}{c}\text { EQUIPMEN } \\
\text { T }\end{array}$ & TEST NUMBER \\
\hline 1. & $\begin{array}{c}\text { Colourfastness } \\
\text { to light }\end{array}$ & $\begin{array}{c}\text { Sunlight } \\
\text { Exposure } \\
\text { Rack }\end{array}$ & AATCC-RR 92, 2013 \\
\hline 2. & $\begin{array}{c}\text { Colourfastness } \\
\text { to washing }\end{array}$ & $\begin{array}{c}\text { Launder-O-M } \\
\text { eter }\end{array}$ & IS:3361-2003(test-2) \\
\hline 3. & $\begin{array}{c}\text { Colourfastness } \\
\text { to rubbing }\end{array}$ & Crockmeter & AATCC-RA 38, 2005 \\
\hline 4. & $\begin{array}{c}\text { Colourfastness } \\
\text { to perspiration }\end{array}$ & Perspirometer & AATCC-RA 52, 2006 \\
\hline
\end{tabular}

\section{Results and Discussion}

\subsection{Hand of the fabric}

It is evident from the figure 1 that the texture of control sample was fair [2] in terms of softness and smoothness, while scoured samples became smooth as compared to control sample and showed good [3] smoothness. In case of protease enzyme treated fabric it was found that with the increase in concentration of enzyme, the fabric softness and smoothness also get increased. Among the various concentrations tried the fabric treated with $4 \mathrm{~g} / \mathrm{l}$ concentration showed excellent [5] softness and excellent [5] smoothness as compared to other concentrations. (Fig.1)

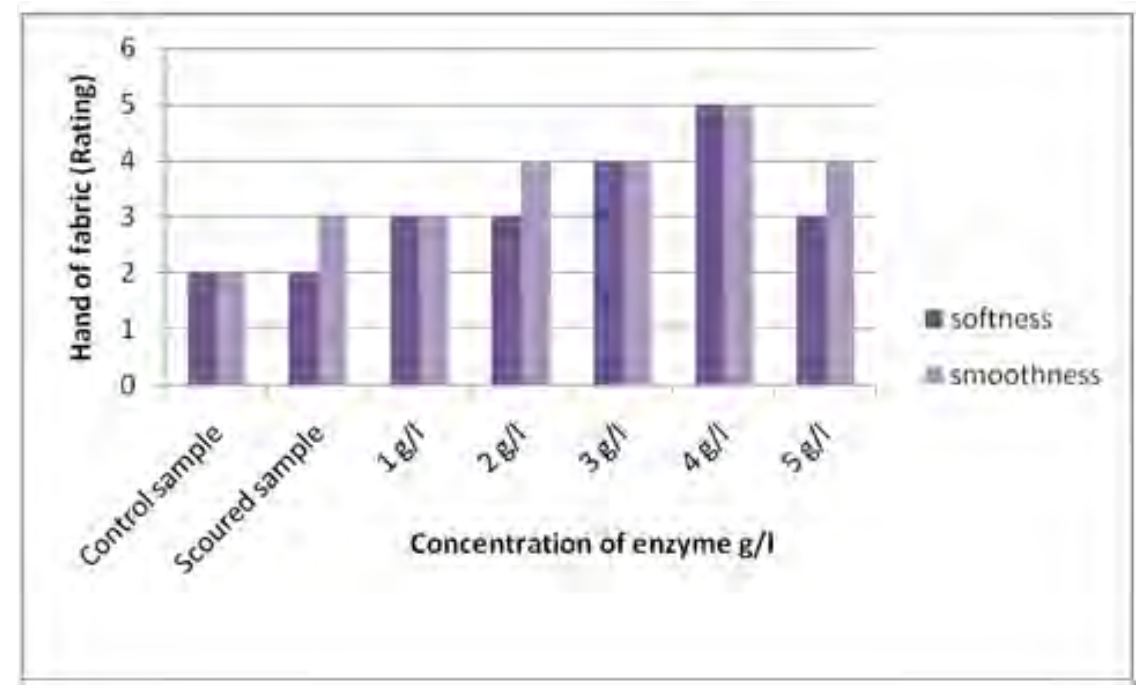

Figure 1. Effect of various concentrations of protease enzymes on the hand (feel) property of wool fabric. 
Table1. Effect of various concentrations of Proteases enzyme treatment on Physical properties of woollen fabric.

\begin{tabular}{|c|c|c|c|c|c|c|c|c|c|c|}
\hline \multirow{2}{*}{ Sl. No. } & \multirow{2}{*}{$\begin{array}{l}\text { Types of } \\
\text { treatments }\end{array}$} & \multirow{2}{*}{$\begin{array}{c}\text { Concentration of } \\
\text { Protease enzyme (g/l.) }\end{array}$} & \multicolumn{2}{|c|}{ Hand of fabric (Rating) } & \multirow{2}{*}{$\begin{array}{c}\text { Weight Loss } \\
\text { (\%) }\end{array}$} & \multirow{2}{*}{$\begin{array}{c}\text { Absorbency } \\
\text { (Time taken in } \\
\text { seconds) }\end{array}$} & \multicolumn{2}{|c|}{$\begin{array}{c}\text { Fabric tensile strength } \\
\text { (newton) }\end{array}$} & \multirow[t]{2}{*}{ Fabric drape (\%) F } & \multirow[t]{2}{*}{$\begin{array}{l}\text { Pilling } \\
\text { (Rating }\end{array}$} \\
\hline & & & Softness & Smoothness & & & Warp & Weft & & \\
\hline 1. & Control & - & 2 & 2 & - & 60 & 42 & 40 & 0.85 & 5 \\
\hline 2. & Scoured & - & 2 & 3 & 0.52 & 45 & 40 & 36 & 0.75 & 5 \\
\hline \multirow{5}{*}{3.} & \multirow{5}{*}{ Protease treated } & 1 & 3 & 3 & 1.47 & 42 & 34 & 35 & 0.67 & 5 \\
\hline & & 2 & 3 & 4 & 2.73 & 38 & 32 & 37 & 0.65 & $4-5$ \\
\hline & & 3 & 4 & 4 & 4.10 & 35 & 33 & 36 & 0.64 & 4 \\
\hline & & 4 & $5 *$ & $5 *$ & 5.36 & 33 & 32 & 32 & $0.48 *$ & 4 \\
\hline & & 5 & 3 & 4 & $6.31 *$ & $31^{*}$ & $31 *$ & $32 *$ & 0.61 & 3* \\
\hline
\end{tabular}




\subsection{Weight Loss (\%)}

It is evident from the table 1 that scoured sample showed minimum weight loss $(0.52 \%)$ as compared to enzyme treated samples. In case of treated fabric it was found that with the increase in concentration of enzyme, the loss in weight also get increased. Among the various concentrations tried the fabric treated with $5 \mathrm{~g} / \mathrm{l}$ concentration showed maximum weight loss $(6.31 \%)$ as compared to other concentrations.

\subsection{Scanning Electron Microscope (SEM) Test}

SCM test was carried out for control, scouring and enzyme treated fibres to study surface morphology of wool fibres on two magnifications i.e. $2.00 \mathrm{~K} \mathrm{X}$ and $5.00 \mathrm{~K} \mathrm{X}$ and these are shown in plates 1 to 7 .

SEM images showed that untreated wool fibre was rough and scales were sharp. The surface scales of wool fibre got blunt and the smoothness of surface was found to increase with increase in enzyme concentration and subsequently resulted in improvement in the comfort factor of wool.

Mag= $2.00 \mathrm{~K} \mathrm{X}$

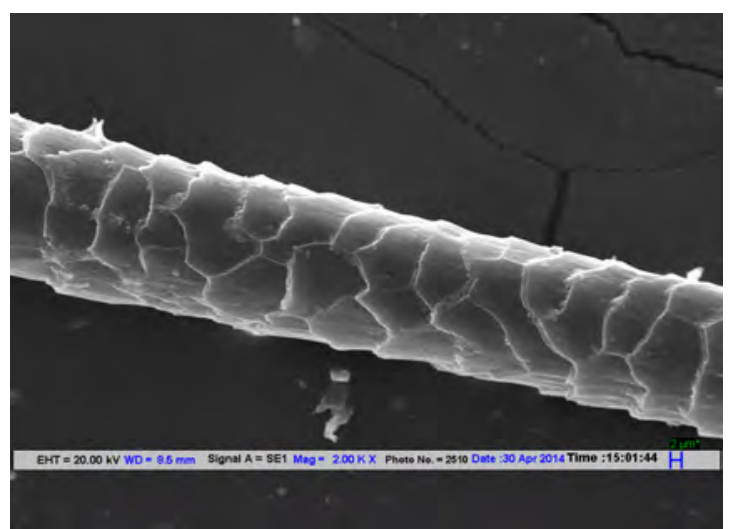

$\mathrm{Mag}=5.00 \mathrm{~K} \mathrm{X}$

Plate 1-Control fibres
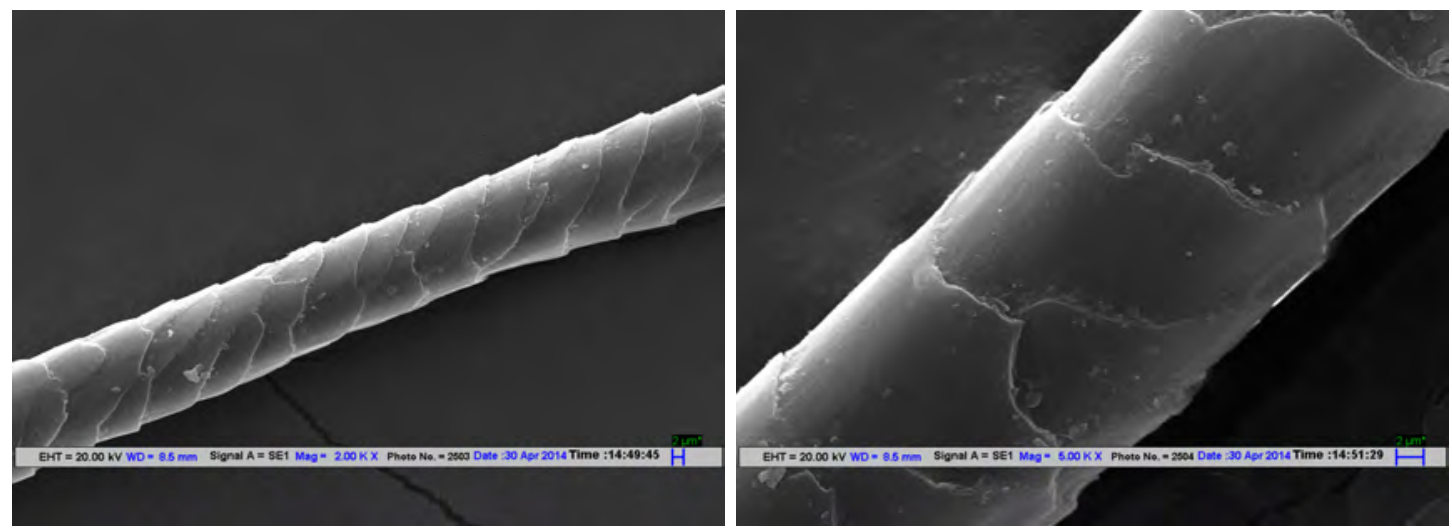

Plate 2-Scoured fibres
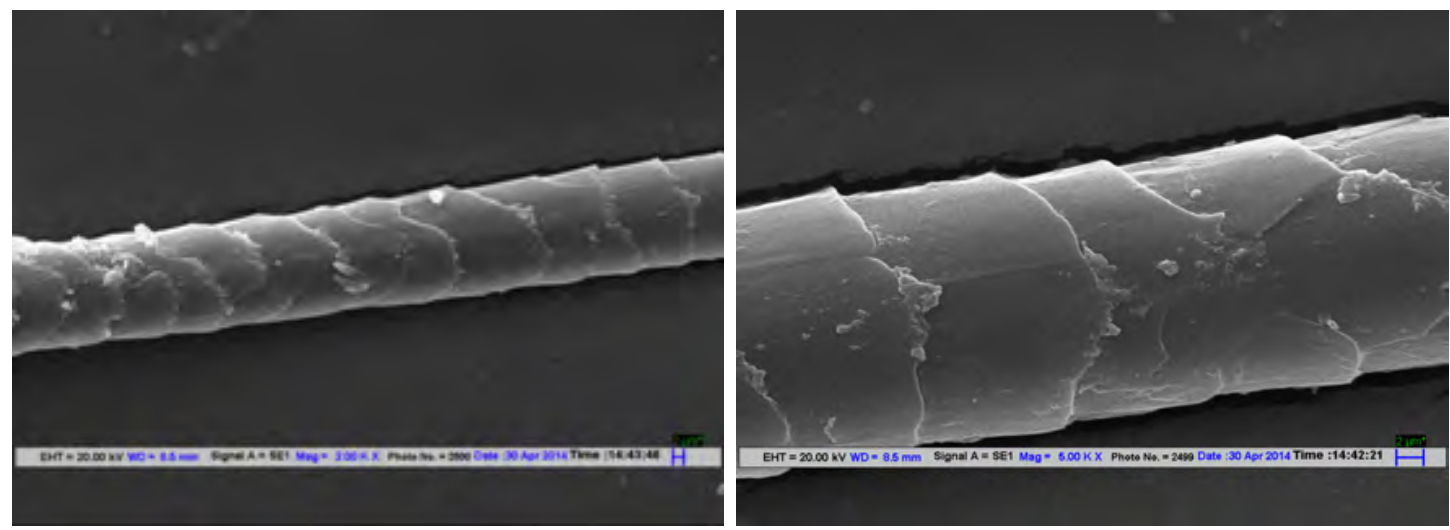

Plate 3- 1 g/l. protease enzyme treated fibres 

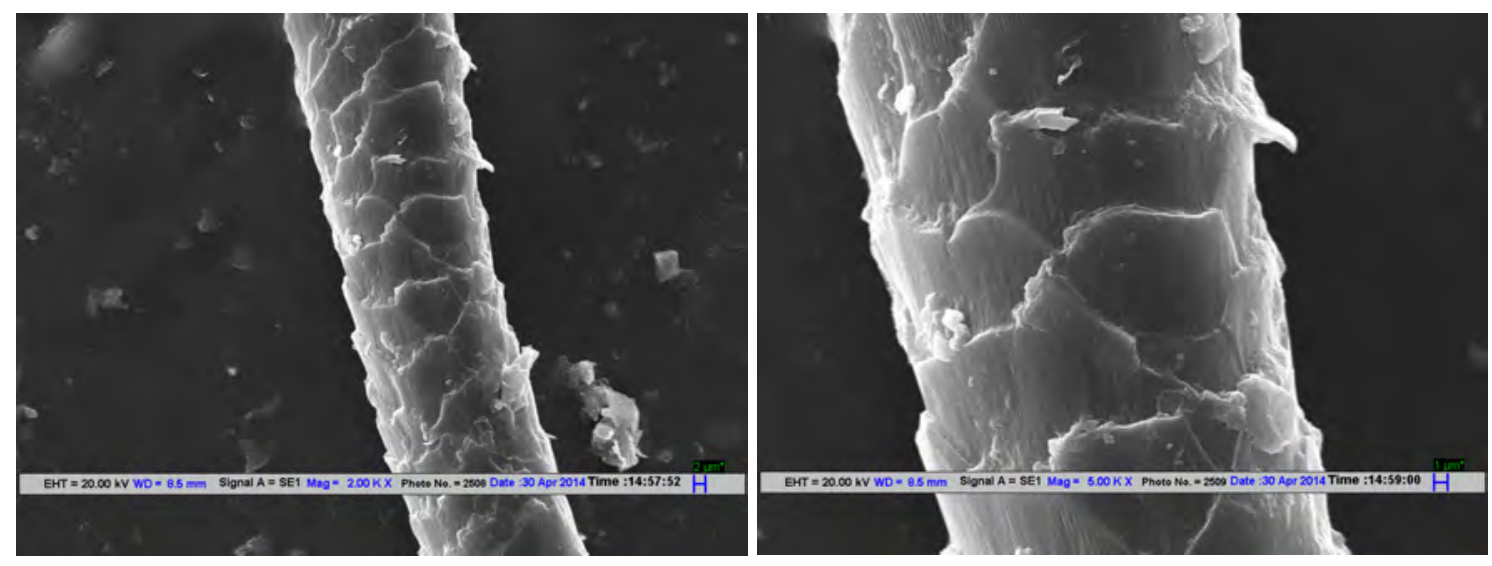

Plate 4- 2 g/l. protease enzyme treated fibres
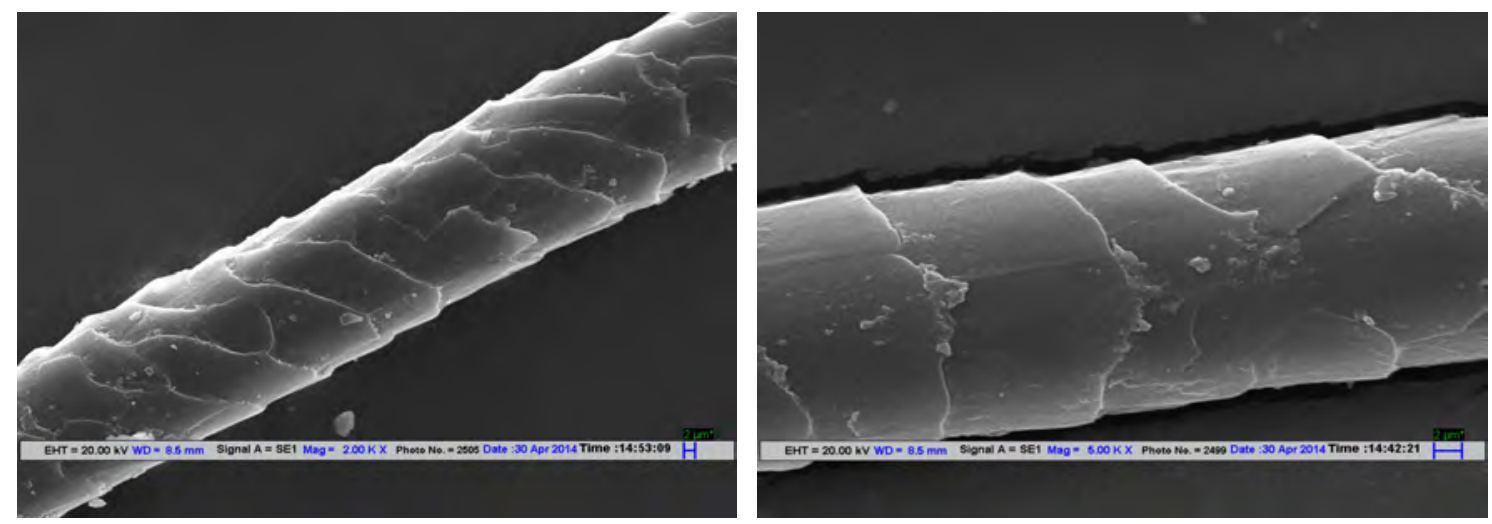

Plate 5- 3.0 g/l. enzyme treated fibre.
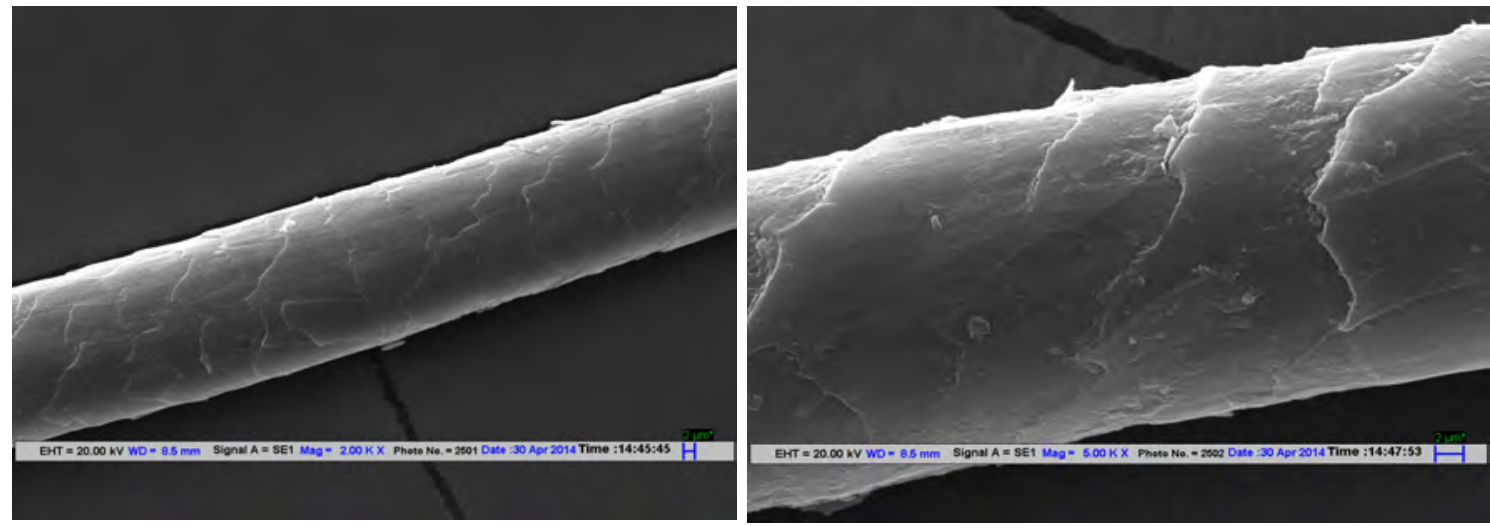

Plate 6- $4.0 \mathrm{~g} / \mathrm{l}$. protease enzyme treated fibres.
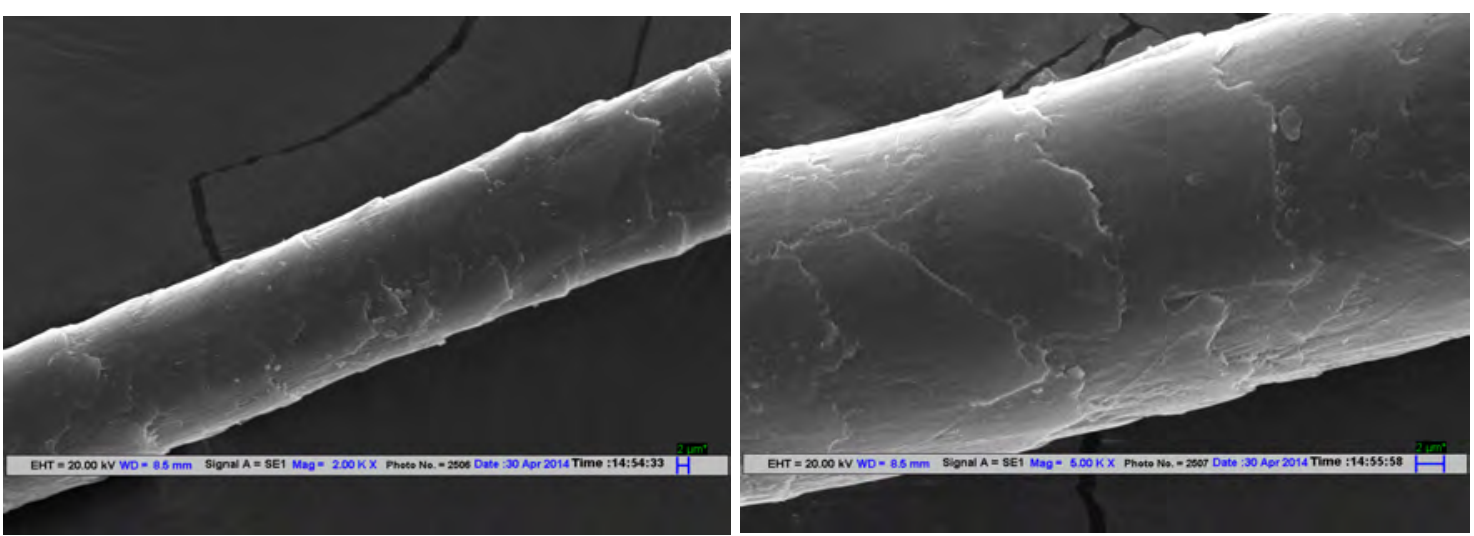

Plate 7- $5.0 \mathrm{~g} / \mathrm{l}$. protease enzyme treated fibres. 


\subsection{Pilling Tendency}

Pilling test was carried out by using "Pilling tester". It is evident from the table 1 that control and scoured samples showed no pilling [5] whereas in case of enzyme treated samples, the pilling tendency increased slightly with the increase in concentration of enzyme treatment. Table clearly reveals that lowest concentration of enzyme $(1 \mathrm{~g} / \mathrm{l})$ shows no pilling [5] and highest concentration (5g/l) of enzyme showed moderate pilling. This may be due to weakening of fibres as proteolytic enzymes damage the surface cuticle and cortex region up to some extent.

Enzyme can penetrate into the core of the fibres, and cause damage to the cortex region apart from damaging the surface cuticle.

\subsection{Fabric Absorbency}

All the samples (controlled, scoured and enzyme treated) were subjected to absorbency test after each treatment by using "Drop tester" and the results are reported in Table 1. It was observed that the control sample showed no absorbency within 60 seconds and after scouring it was improved and took maximum 45 seconds time for water to absorb completely by the fabric. It was also found that after enzyme treatment of the samples, the absorbency of fabric improved. Table clearly reveals that once the percent of concentration has increased, the amount of time for the water drop to be absorbed decreased indicating that proteases treatment helped to remove some of the hydrophobic compounds on wool surface. (Fig 2)

\subsection{Tensile Strength}

Fabric tensile strength test was carried out on "Tensile strength tester" and results are reported in Table 1. It shows that increase in the concentration of protease led to a decrease in the tensile strength in both warp and weft direction, which was in accordance with the results of weight loss. As the weight loss increases, the strength decreases, due to the higher hydrolysis of protein chains occurring with higher concentrations of proteases. With higher hydrolysis, the length of polypeptide chains in the proteins of wool decreases, and a lower energy is needed for the separation of chains and breakage of the fabric.

\subsection{Drapability}

"Drape meter" was used to check the fabric drape. The highest percent value of fabric drape shows minimum drapability. It is evident from table 1 that the control sample showed highest value (0.85) of drape which represented minimum drapability. This may be due to the reason that the presence of various impurities like fats, oils, waxes and starch make the fabric stiffer which ultimately contribute to lower drapability. However, scouring and enzyme treatment removed these impurities thereby making the samples to show better drapability than control fabric.

Among the various concentrations tried the fabric treated with $4 \mathrm{~g} / \mathrm{l}$ concentration showed maximum drape $(0.48)$ as compared to other concentrations. This concentration of enzyme treatment showed best result of fabric drape.

\subsection{Colourfastness Testing of Wool Fabric Dyed With Acid Dye}

\subsubsection{Colourfastness to light}

Colourfastness to light was examined by using "sunlight exposure rack". In the study, fading was taken as a criterion for light fastness of dyed samples dyed with acid dye. Fading of samples was evaluated by comparing the exposed and unexposed portion of the samples in contrast to the blue wool standards and the results of the light fastness of samples are presented in the Table 2 .

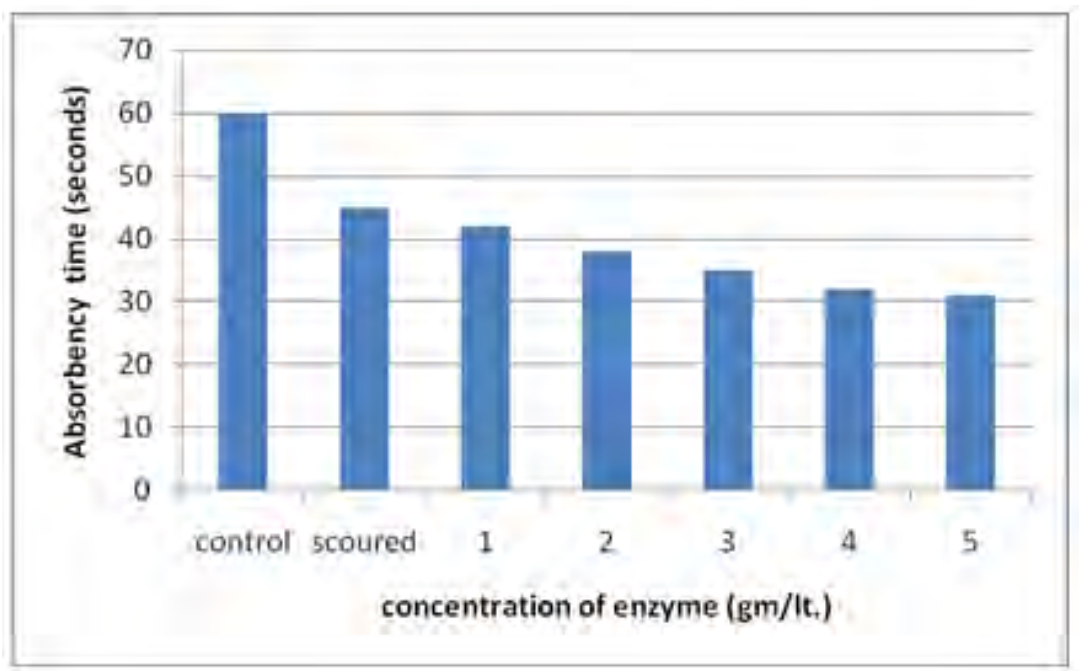

Figure 2. Effect of various concentrations of enzymatic treatment on Absorbency of woollen fabric. 
Table 2. Effect of Acid dye on colourfastness properties of woollen fabric.

\begin{tabular}{|c|c|c|c|c|c|c|c|c|c|c|c|c|c|}
\hline \multirow{3}{*}{ Sl. No } & \multirow{3}{*}{$\begin{array}{l}\text { Types of } \\
\text { treatments }\end{array}$} & \multirow{3}{*}{$\begin{array}{c}\text { Conc. of } \\
\text { Protease } \\
\text { enzyme } \\
\text { (g/lit.) }\end{array}$} & \multirow{3}{*}{$\begin{array}{l}\text { Colour } \\
\text { fastness to } \\
\text { light }\end{array}$} & \multicolumn{2}{|c|}{$\begin{array}{l}\text { Colour fastness to } \\
\text { washing }\end{array}$} & \multicolumn{2}{|c|}{$\begin{array}{l}\text { Colour fastness to } \\
\text { Crocking/Rubbing }\end{array}$} & \multicolumn{6}{|c|}{ Colourfastness to perspiration with Acid dye } \\
\hline & & & & \multirow{2}{*}{$\begin{array}{l}\text { Colour } \\
\text { change }\end{array}$} & \multirow{2}{*}{$\begin{array}{l}\text { Colour } \\
\text { staining }\end{array}$} & \multirow{2}{*}{ Dry } & \multirow{2}{*}{ Wet } & \multicolumn{2}{|c|}{ Staining (wool) } & \multicolumn{2}{|c|}{ Staining (cotton) } & \multicolumn{2}{|c|}{ Change in colour } \\
\hline & & & & & & & & Acid & Alkaline & Acid & Alkaline & Acid & Alkaline \\
\hline 1. & Control & - & 6 & $3 / 4$ & $3 / 4$ & 4 & $3 / 4$ & $2 / 3$ & 2 & 3 & 3 & $4 / 5$ & $4 / 5$ \\
\hline 2. & Scoured & - & 7 & 3 & 3 & $4 / 5$ & $3 / 4$ & $2 / 3$ & 2 & 3 & 3 & $4 / 5$ & 4 \\
\hline \multirow{5}{*}{3.} & \multirow{5}{*}{$\begin{array}{c}\text { Protease } \\
\text { treated }\end{array}$} & 1 & 5 & 3 & $3 / 4$ & 4 & $3 / 4$ & 2 & 2 & 3 & 3 & 4 & 4 \\
\hline & & 2 & 6 & 3 & $3 / 4$ & 4 & $3 / 4$ & 2 & $2 / 3$ & $3 / 4$ & $3 / 4$ & $4 / 5$ & $4 / 5$ \\
\hline & & 3 & 8 & 3 & $3 / 4$ & 4 & $3 / 4$ & $2 / 3$ & $2 / 3$ & $3 / 4$ & $3 / 4$ & $4 / 5$ & $4 / 5$ \\
\hline & & 4 & 8 & $3 / 4$ & 4 & $4 / 5$ & 4 & 3 & 3 & 4 & $3 / 4$ & 5 & $4 / 5$ \\
\hline & & 5 & 8 & $3 / 4$ & 4 & $4 / 5$ & 4 & 3 & 3 & 4 & $3 / 4$ & 5 & $4 / 5$ \\
\hline
\end{tabular}




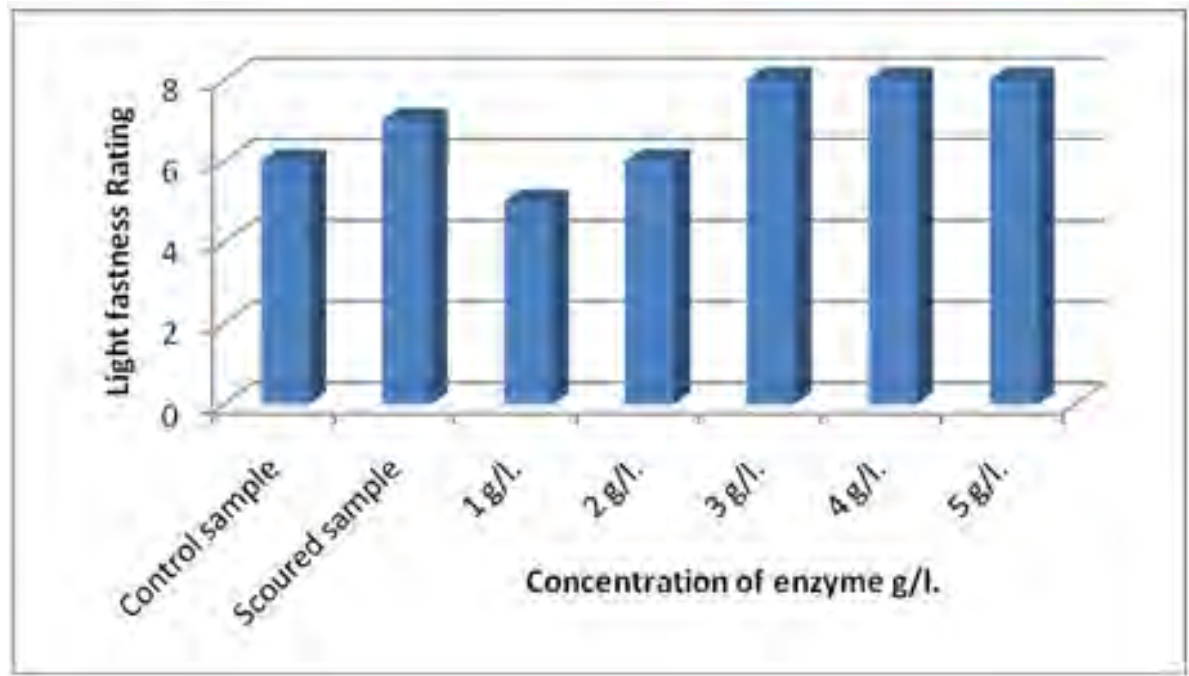

Figure 3. Effect of various concentrations of enzyme treatment on lightfastness of woollen fabric.

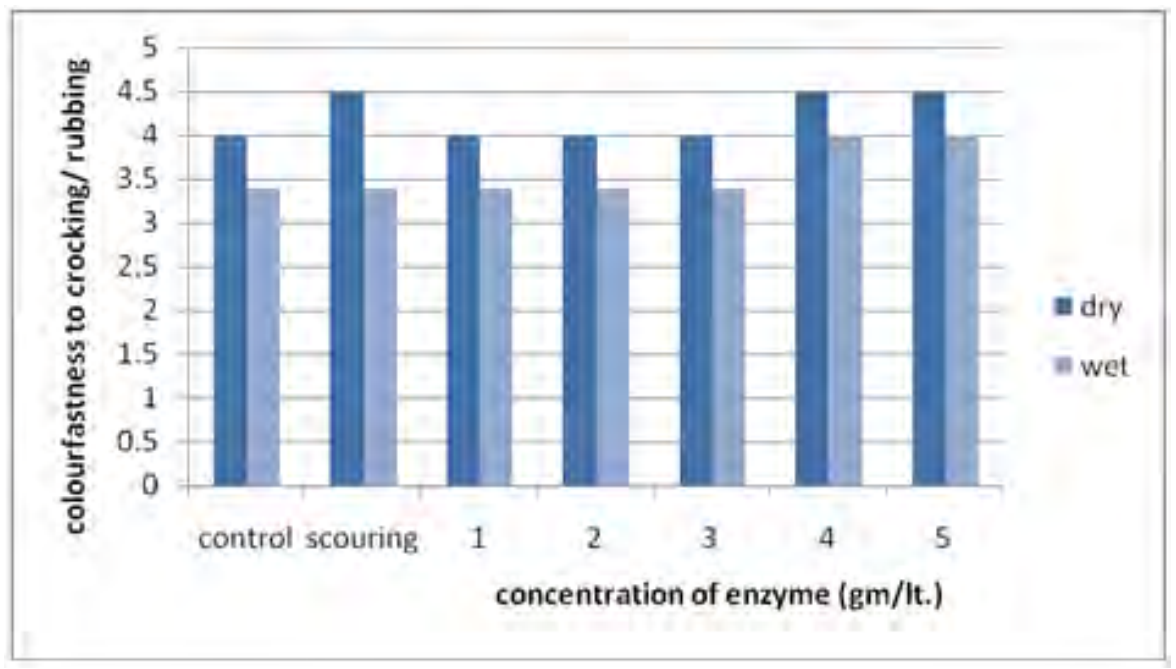

Figure 4. Effect of various concentrations of enzymatic treatment on crocking/rubbing fastness on woollen fabric.

It was found that control and scoured samples dyed with acid dye showed very good [6] and excellent [7] light fastness respectively while enzyme treated samples showed light fastness rating between 5 to 8 . The highest concentration of enzyme treatment brought outstanding results with 8 rating on grey scale. (Fig 3).

\subsubsection{Results of Colourfastness to crocking/rubbing}

"Crockmeter" was used to observe the colourfastness to crocking/ rubbing. It was observed that the control and scoured samples of wool fabric showed very good [4] and very good to excellent rubbing fastness respectively with dry test cloth and noticeable to slight [3/4] colour staining for wet crocking (Figure 4). It was observed that among enzyme treated samples, $4 \mathrm{~g} / \mathrm{l}$ and $5 \mathrm{~g} / \mathrm{l}$ gave best results for rubbing fastness with acid dye in both dry and wet state. They showed very good to excellent rubbing fastness and slight staining for wet crocking.

\subsubsection{Results of Colourfastness to washing}

"Launder-O-meter" was used to find out the effect of acid dye on colourfastness to washing. It was found that the control sample showed good to very good colour change [3/4] and noticeable to slight colour staining [3/4]. Scoured sample showed good [3)colour change and noticeable [3] colour staining. While enzyme treated samples showed improvement in colour change and colour staining with increase in concentration of enzyme per litre of water. Hence it can be concluded that $4 \mathrm{~g} / \mathrm{l}$ and $5 \mathrm{~g} / \mathrm{l}$ samples gave best results for colour change and colour staining i.e good to very good [3/4] colour change and slight staining [4] in both the cases.

\subsubsection{Results of Colourfastness to perspiration:}

The perspiration fastness was carried out using "Perspirometer". Results from the table 2 reveals that the control sample of wool fabric showed very good to excellent [4/5] perspiration fastness in both acid and alkaline solution. Among enzyme treated samples, $5 \mathrm{~g} / \mathrm{l}$ samples showed excellent [5] colour change in acidic medium and very good 
to excellent [4/5] colour change in alkaline medium.

Results for colour staining on cotton fabric showed that cotton fabric gave noticeable [3] colour staining for control sample in both the solutions, whereas in case of enzyme treated fabric $4 \mathrm{~g} / \mathrm{l}$ and $5 \mathrm{~g} / \mathrm{l}$ samples gave noticeable to slight [3/4] colour staining for alkaline solution and slight staining [4] in acidic solution.

Results for colour staining on wool fabric revealed that control fabric had considerable [2] staining in alkaline medium and considerable to noticeable [2/3] staining in acidic medium. For enzyme finished wool fabric $4 \mathrm{~g} / \mathrm{l}$ and 5 g/l showed best results i.e noticeable [3] colour staining in both alkaline and acidic solutions. While comparing colour staining on cotton and wool fabric, colour staining on cotton fabric gave best results as compared to wool fabric in both alkaline and acidic medium.

\section{Conclusions}

Enzyme treatment on woven woolen fabric causes the scales to be flattened thereby made the fabric smooth and soft. It also improved other physical properties including hand, drapability, absorbency, dye ability and colour fastness properties. While tensile strength decreased slightly. It improved the softness and thereby reduced the subjective prickle of the fabric. Among various concentrations of enzyme, $4 \mathrm{~g} / \mathrm{l}$ enzyme concentration showed best results in all aspects.

\section{REFERENCES}

[1] AATCC Technical Manual. 2010. Technical Manual of the American Association of Textile Chemists and Colorists. Research Triangle Park, N.C., USA

[2] ASTM. 2012. American Society for Testing and Materials, Pennsylvania, United States.

[3] Angappan, P. and Gopalkrishhnan. R. 1993. Textile Testing. 3rded. Tamil Nadu. S.S.M.I.T.T. Students Co-op. Stores Ltd. $485 \mathrm{p}$.

[4] Bureau of Indian Standards. 2010. Bureau of Indian standards Publication, Manak Bhawan, New Delhi.

[5] Dantyagi, S. 2006. Fundamentals of Textiles and their care, Orient Langman Ltd., New Delhi. 5thed, pp 154-161.

[6] Ramin, M. and Montazer, A. 2010. Influence of Proteases and Trans-gluminases on wool. Fibres and Textiles in Eastern Europe. 2(79): 98-102.

[7] Shenai, V.A. 1984. Technology of Textile Processing: Technology of Dyeing. 6th ed. Bombay, Sevak Publication. 490p.

[8] Silva, C.J.S.M.; Cavaco-Paulo, A. 2003.Treatment of animal hair fibers with modified proteases. Patent WO03097927.

[9] Udakhe, J.; Tyagi S.; Srivastava N.; Honade S. and Bhute A. 2012. Effect of yarn hairiness, DBD plasma and enzyme treatment on itching propensity of woollen knitwear. Colourage, 59(5):46-51

[10] http://www.astm.org/Standards/textile-standards.htm 